\title{
Issues of Coordinated Cooperation for Forming Leasing Payments Schedules
}

\author{
Ajupov A. A. ${ }^{1}$, Kurilova A. A. ${ }^{2}$ \& Ozernov R. S. ${ }^{3}$ \\ ${ }^{1}$ Kazan Federal University, Institute of Management, Economics and Finance, Kazan, Russia \\ ${ }^{2}$ Togliatti State University, Togliatti, Russia \\ ${ }^{3}$ Samara State Aerospace University, Samara, Samara \\ Correspondence: Kurilova A. A., Togliatti State University, Togliatti, 445667, Russia. Tel: 7-917-122-3879. \\ E-mail: aakurilova@yandex.ru
}

Received: December 27, 2014 Accepted: February 19, 2015 Online Published: April 30, 2015

doi:10.5539/ass.v11n11p23 URL: http://dx.doi.org/10.5539/ass.v11n11p23

\begin{abstract}
In the article there are adduced main components of the one of possible schemes for the solution of Russian aircraft complex problems managing on the base of leasing mechanism. There is formulated the model of payments' flows, which characterize interaction of aviation leasing project participants, and developed the model for forming leasing payments schedule, which guarantees co-ordination of participants' economic interests in the "lessor-lessee" system.
\end{abstract}

Keywords: the positions of the Russian aviation complex, economic mechanisms of leasing relations in aviation, models for organization of coordinated economic cooperation

\section{Introduction}

Aviation Complex has always been and remains one of the leading sectors of the Russian engineering industry. Many scientific and technological developments and innovations, which have no analogues abroad, received its implementation here. According to its scientific and innovative potential, it is able to produce products that can be competitive on world markets. However, now it faced a number of challenges, one of which is the aircraft fleet update. This problem occurs on the background of the economy deregulation from 1990 to 2000 . There was a sharp decline in the air transport performance, which had no analogues in the world civil aviation history.

Since 2000 air transport market began gradual recovery of its lost ground. Today it accounts for more than $12 \%$ of passenger traffic and about $1 \%$ of freight traffic on the Russian general.

However, the Russian fleet carriers are in critical condition, and this is one of the main reasons for their low competitiveness. Despite the fact that the airlines are trying to get rid of aging aircraft, currently the bulk of their fleet are aircrafts developed and produced in 1960-1980 years. These airplanes are ousting from international lines with new, more stringent ICAO standards for noise, air emissions and airplane driving accuracy, before the write-off for their resource working off. In recent years competition of Russian and foreign airlines on international air travel markets sharply increased. Foreign airlines, equipped with a modern aircraft fleet, are more competitive in terms of the imposed restrictions on international flights. At the moment, the vast majority of airlines operate with Soviet equipment with a high level of moral and technical obsolescence.

The main problems are updating the material and technical base and modification of fixed assets in the aviation industry. Carriers currently lack the resources to purchase new aircraft that meets international standards. International and domestic experience shows that probably the only way to resolve existing problems for the Russian state at this stage is using the one of still relatively new and non-traditional methods of hardware updating - leasing of aircraft.

\section{Theory}

Consideration of problems related to leasing issues is reflected in the articles and papers of many researchers. There have been developed methods for calculating the lease payments are set forth criteria for evaluating the leasing effectiveness comparing to other forms of management. However, papers, which present methods for quantitative assessments of proposed solutions, are not enough. Moreover, the vast majority of the authors focus 
on the interests of only one of the leasing relations participants - bank, lessor or lessee. At the same time it is evident that the entire system efficiency is determining by the methods of constructing the mechanisms for interaction of all elements. One of the effective tools for solving such class of problems is the theory of active systems, the basic situation and the results of which were described and published by Russian and foreign scientists. Published works include the results of basic research in the management for complex organizational systems. At the same time, the methodology and tools of this theory, implemented in the language of set-theoretic descriptions, require specification and adaptation to the specific applications.

Below there will be discussed issues of the developing effective mechanisms for using leasing by aircraft companies, taking into account economic interests of participants in the interaction of leasing transactions, as well as their practical significance.

For airlines and airline-like companies such way of managing is attractive at the time of the temporary need for equipment (aircraft equipment, machinery, special transport, and so on). The airline needs to lease in case it has no possibility to use the loan for the purchase of necessary aircraft and equipment for the operation. Or the airline can decide to use its own financial capital and borrowed funds in another way. Components of the lease payments are shown in Figure 1.

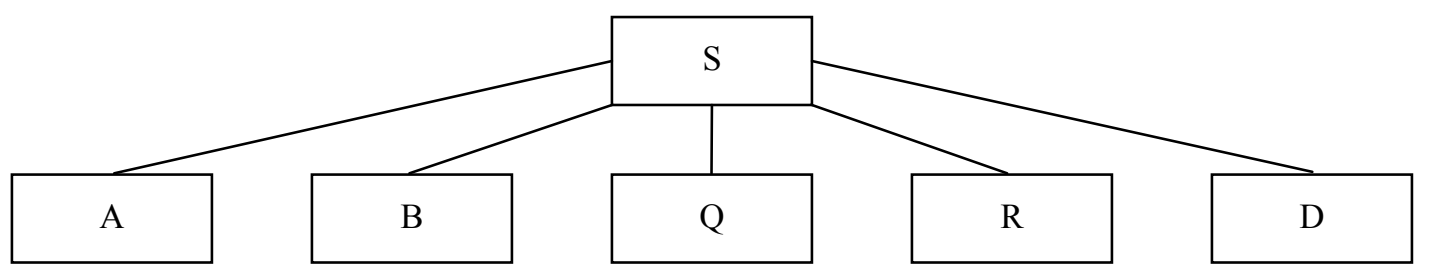

Figure 1. Total amount of the lease payments

$$
S=A+B+Q+R+D,
$$

where $S$ - total amount of lease payments for the entire period of the leasing contract; $A$ - amounts that recover value of the leased property during the period of the lease agreement; $B-$ a commission to the lessor; $Q-$ payment to the lessor for the credit facilities that he used for the purchase of property - the leased asset; $R-$ the amount that is paid to the lessor for the insurance of leased property, if it was insured by the lessor; $D$ - other costs of lessor under the leasing contract.

The economic logic of leasing operations is that the most importantly for the airlines is not to own the aircraft, but to use them for making profit. Thus the direct owner (as well as company which holds an aircraft on its balance and, therefore, pays property tax) may not be the airline.

Payments under a lease agreement can be monthly, quarterly, semi-annual and annual. They are agreed in the contract (agreement). Monthly payments are made after the signing of the lease agreement. Payments under the contract are usually equal to each other, but the schedule of their work can be made to suit the needs of a particular lessee. Also lease payments within the first year can be reduced under the agreement concluded between the lessor and the lessee. Leasing agreement provides the possibility for returning of leased aircraft to the owner (lessor) at the end of the lease contract. Leasing agreement also entitles the lessee to buy airplanes for the residual value or extend the lease for a new term of use.

Leasing transactions are considered by the business world, first of all, as the most relevant type of financing, and not only because they provide financial assistance to needy enterprises. They are considered in such way also because in certain circumstances they can provide economic benefits for the financially strong enterprises basing on the tax laws. Other benefits are also clearly visible: preservation of liquidity, no immobilization of equity, a solid basis for the calculations, flexibility, balance benefits, the benefits for insurance.

The basic elements in schemes for the leasing operations that interact in the leasing procedures are: equipment supplier (manufacturer); the lessor; bank; the lessee. Present paper focuses on the mechanisms of interaction between the lessor and the lessee. And the lease payments are economic instrument reflecting this interaction. 


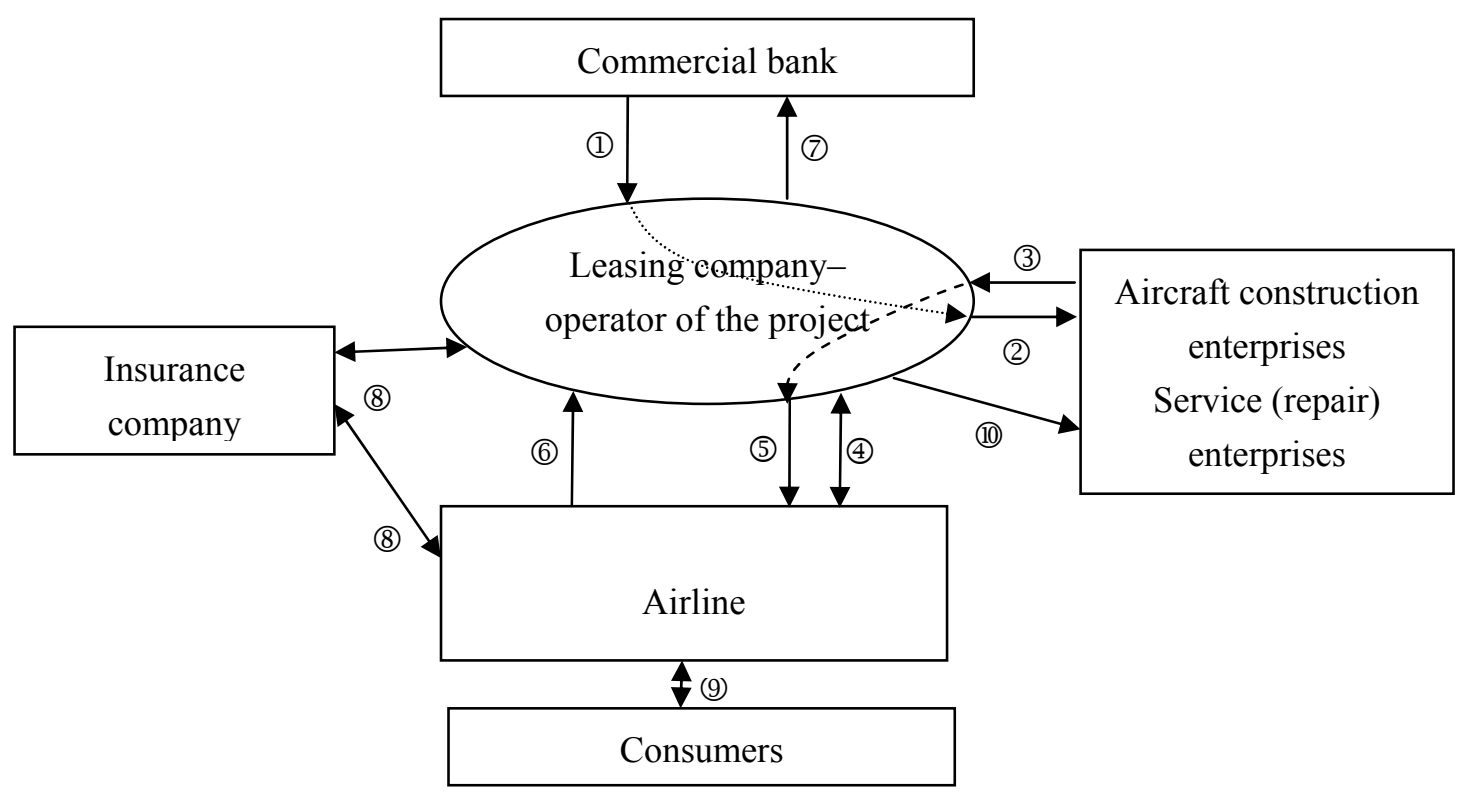

(1) - the leasing company obtains credit for the aircraft purchase; (2) -leasing company finances aircraft building; (3) - leasing company repurchases the property of the plane at an aircraft factory; (4) - signing of the lease agreement; (5) - supply of complete aircraft to the air carrier; (6) - receipt of lease payments by the leasing company; (7) - repayment of the loan by the leasing company to a commercial bank; (8) - conclusion of the insurance contract (leasing company insures the aircraft and carrier insures the responsibility of the crew); (9) implementation of transport services to consumers; cash flows; (10)-payments on current obligations.

Figure 2. The scheme of interaction between participants of aircraft financial leasing project

Using the circuit shown on Figure 2 allows solving following fundamental problems:

- Recover commercial communications between production companies, that have been lost during the privatization period, to overcome fragmentation of enterprises that make up the core of the aviation manufacturing industry; to increase the production and marketing of aircraft;

- Provide an opportunity for operators to implement the acquisition of aviation equipment without one-time accumulation of large amounts of funds and loans; to carry out the necessary modernization of aircraft park and renovation of outdated equipment and facilities;

- Provide external impulse to start the interaction of all stakeholders in order to eliminate the whole aviation system from the crisis.

The lease payments according to the schedule enshrined in the lease agreement act as cash flow. Graphs of the lease payments that are tailored to the interests of airlines and leasing companies may vary. Decision models for airlines and leasing companies were formulated to reconcile the interests of participants of the leasing transaction. They will be considered consistently below.

We consider the schedule for the paying of lease payments (debt repayment) $r=\left(r_{1}, \ldots, r_{i}, \ldots, r_{T}\right)$, which the carrier (debtor) pays to the leasing company, which in this case acts as a lender. Here $r_{i}$-amounts paid by the air carrier to the lessor in periods $i=1, \ldots, \mathrm{T}$, and the amount of payments should eventually provide redress for the total lease payments $S$.

In this case, the strategy of the airline is to choose the payment schedule $r^{*}=\left(r_{1}{ }^{*}, \ldots, r_{i}^{*}, \ldots, r_{T}^{*}\right)$, which is made on the basis of analyzing the structure of assets and economic opportunities of the airline enterprise. In its turn, the leasing company in pursuit of its goals and interests, develops an optimal, from his point of view, reimbursement schedule of lease payments $r^{0}=\left(r_{1}^{0}, \ldots, r_{i}^{0}, \ldots, r_{T}^{0}\right)$.

In practice, the lease payment schedules, independently developed by the airline and leasing company, by virtue of their different interests, as a rule, are not the same to each other. Therefore, it is necessary to choose coordinating options to agree payments on a timetable. It is proposed to change the payment schedule developed by the airline $\Delta r=\left(\Delta r_{1}, \ldots, \Delta r_{i}, \ldots, \Delta r_{T}\right)$. And coordinating the parameters must satisfy the following conditions: 
first, to provide additional financial effect for the lender (leasing company), and, at the same time, a positive cash flow for the debtor (air carrier).

Objective function for airlines $f(r)$ can be established as a discounted difference between the expected return $H(q)$, and the sum of the current costs $z(q)$ and the lease payments $r$ :

$$
f(r)=\sum_{i=1}^{T} \frac{\left(H_{i}\left(q_{i}\right)-z_{i}\left(q_{i}\right)\right)-r_{i}}{(1+\alpha)^{i}},
$$

where $H_{i}\left(q_{i}\right)$ - expected return for airline in the $i$-th time period, $q_{i}$ - the volume of services, implemented by the airline in the period $i$ (can be expressed, for example, in tonne- or passenger-kilometers), $z_{i}\left(q_{i}\right)$ - operating costs associated with implementation of services for transportation in orders $q_{i}, \alpha$ - the discount rate.

Thus, the model of decision-making about choosing the repayment schedule for the airline will be as follows:

$$
\left\{\begin{array}{l}
f(r)=\sum_{i=1}^{T} \frac{\left(H_{i}\left(q_{i}\right)-z_{i}\left(q_{i}\right)\right)-r_{i}}{(1+\alpha)^{i}} \underset{r_{i}}{\longrightarrow} \max , \\
q_{i} \leq \min \left(Q_{i}, P_{i}\right) \\
\sum_{i=1}^{T} r_{i}=S \\
\forall i=1, \ldots, T \quad \sum_{\tau=1}^{i}\left(H_{\tau}\left(q_{\tau}\right)-z_{\tau}\left(q_{\tau}\right)\right)-r_{\tau} \geq 0 \\
\forall i=1, \ldots, T \quad z_{i}\left(q_{i}\right)=a_{i} \cdot q_{i}+C_{F} \\
r_{i} \geq 0,(i=\overline{1, T})
\end{array}\right.
$$

where $Q_{i}$ - the production capacity of leased equipment, $P_{i}$ - applications for air transportation, $S$ - total amount of the lease payments, $a_{i}$ - standard costs of operating expenses for servicing orders.

The result of model (1) decision is the schedule of lease payments $r^{*}=\left(r_{1}^{*}, \ldots, r_{i}{ }^{*}, \ldots, r_{T}^{*}\right)$, which is optimal for airline in payments terms.

Now we consider the problem of decision-making, which is making the schedule of lease payments from the standpoint of the lessor economic interests.

Optimality criterion in this case should be the net present value of the lessor. It is defined as the difference between the discounted lease payments $r_{i}$, which it receives from the lessee, and its own operating costs $C_{i}$, related to the financial supply and security of the leasing contract.

With that said decision-making model of the lessor to the scheduling of payments $r$, optimal from his point of view, is of the form:

$$
\left\{\begin{array}{l}
\Phi(r)=\sum_{i=1}^{T} \frac{r_{i}-C_{i}}{(1+\alpha)^{i}} \underset{r_{i}}{\longrightarrow} \max , \\
\sum_{i=1}^{T} r_{i}=S, \\
\forall i=1, \ldots, T \quad r_{i} \leq H_{i}-z_{i} .
\end{array}\right.
$$

Note that substantial sense of restrictions $\left(r_{i} \leq H_{i}-z_{i}\right)$ is that the lessor should consider the economic opportunities of the lessee.

Solution of the model (2) allows to select a payment schedule, the optimum from the point of view of the leasing company interests: $r^{0}=\left(r_{1}^{0}, \ldots, r_{i}^{0}, \ldots, r_{T}^{0}\right)$.

If the payments schedules, determined from the standpoint of airlines $r^{*}$ (model (1)) and the leasing company $r^{0}$ (model (2)), are the same, the interaction in the system is consistent and coordinated. But in practice this happens 
very rarely. If we ignore the restriction, which has been discussed above, it is guided by the optimality criteria in problems (1) and (2), the following solutions are obvious:

$$
\begin{aligned}
& r_{i}^{0}(i=0)=S-\text { the interests of the lessor, } \\
& r_{i}^{*}(i=T)=S-\text { the interests of the lessee. }
\end{aligned}
$$

However, the system operating constraints lead to optimal solutions $r_{i}^{0} \neq r_{i}^{*}$. Range $\Delta=\left[r_{i}^{*}, r_{i}^{0}\right]$ is an area for coordination of economic interests between the lessor and the lessee. Selecting compromise values $r_{i}$ can be accomplished either by using a model (3), where $r_{i}^{*}$ is seen as the initial value, either by using regulatory revenue sharing widely described in the literature.

In order to meet the interests of both parties it is necessary to generate a corrective actions $\Delta r$, which are coordinating the parameters in terms of payments. In this connection we can propose economic-mathematical model to produce an agreed schedule of lease payments, which has the following form (model (3)).

$$
\left\{\begin{array}{l}
f(\Delta r)=\sum_{i=1}^{T} \frac{\left(H_{i}\left(q_{i}\right)-z_{i}\left(q_{i}\right)\right)-\left(r_{i}^{*}+\Delta r_{i}\right)}{(1+\alpha)^{i}} \underset{\Delta r_{i}}{\longrightarrow} \max , \\
q_{i} \leq \min \left(Q_{i}, P_{i}\right), \\
\sum_{i=1}^{T}\left(r_{i}^{*}+\Delta r_{i}\right)=S, \\
\forall i=1, \ldots, T \quad \sum_{\tau=1}^{i}\left(H_{\tau}\left(q_{\tau}\right)-z_{\tau}\left(q_{\tau}\right)\right)-\left(r_{\tau}^{*}+\Delta r_{\tau}\right) \geq 0, \\
\forall i=1, \ldots, T \quad z_{i}=a_{i} \cdot q_{i}+C_{F}, \\
\forall i=1, \ldots, T \quad r_{i}^{*}+\Delta r_{i} \geq 0, \\
\Phi(\Delta r)=\sum_{i=1}^{T} \frac{\left(r_{i}^{*}+\Delta r_{i}\right)-C_{i}}{(1+\alpha)^{i}} \underset{\Delta r_{i}}{\longrightarrow} \max .
\end{array}\right.
$$

While constructing of this model we base on that there are solutions for local optimization models (1), (2) $-r_{i}^{*}$ and $r_{i}^{0}$, reflecting the interests of the lessee and the lessor. Availability of difference $\Delta r_{i}=r_{i}^{*}-r_{i}^{0}$ necessitates corrections for $r_{i}$, aimed at achieving a "reasonable" compromise between the lessor and lessee interests. Introducing the concept of "reasonableness", we have to define a formal measure of its evaluation. For this purpose, we can select an area of feasible solutions for $r_{i}$. Analysis of the models (1) and (2) leads to the conclusion about limiting values $r_{i}$ from the perspectives of the lessor and lessee.

\section{Results}

To illustrate the developed models we can consider the example of the organization of leasing relations between "Aviation leasing company "Tupolev" Ltd. and "Volga-Dnepr" Airline" Joint-Stock Company. Our example covers operating of a Boeing-747 aircraft. Initial data for the calculations are presented in Table 1.

Table 1. Basic data on the leasing contract

\begin{tabular}{ccc}
\hline Leasing period $T$ & 10 & years \\
Airline annual income $H_{i}$ & 38,6 & \$ million \\
Costs $z_{i}$ & 28,4 & \$ million \\
Rate of return $y_{i}$ & 0,35 & \$ mln/thousand tonne-kilometer \\
Unit costs $a_{i}$ & 0,26 & \$ mln/thousand tonne-kilometer \\
Discount rate $\alpha$ & 15 & $\%$ \\
Leasing contract total $S$ & 40 & \$ million \\
\hline
\end{tabular}

Lease payments schedules $\left(r_{i}{ }^{*}\right)$ for "Volga-Dnepr" were calculated using model (1). They reflect the economic interests of the airlines and are shown in Table 2. 
Table 2. The results of calculations on the model (1)

\begin{tabular}{ccccccc}
\hline Period (year), $i$ & $q_{i}$ & $r_{i}^{*}$ & $H_{i}$ & $z_{i}$ & $f(r)$ & Discounted $f(r)$ \\
\hline 1 & 108,8 & 0 & 38,08 & 28,29 & 9,792 & 8,51 \\
2 & 110 & 0 & 38,5 & 28,6 & 9,9 & 7,49 \\
3 & 110 & 0 & 38,5 & 28,6 & 9,9 & 6,51 \\
4 & 112 & 0 & 39,2 & 29,12 & 10,08 & 5,76 \\
5 & 120 & 0 & 42 & 31,2 & 10,8 & 5,37 \\
6 & 120 & 0 & 42 & 31,2 & 10,8 & 4,67 \\
7 & 120 & 7,6 & 42 & 31,2 & 3,2 & 0 \\
8 & 120 & 10,8 & 42 & 31,2 & 0 & 0,00 \\
9 & 120 & 10,8 & 42 & 31,2 & 0 & 0,00 \\
10 & 120 & 10,8 & 42 & 31,2 & 0 & 0,00 \\
Total & & $\mathbf{4 0}$ & & & $\mathbf{6 4 , 4 7 2}$ & $\mathbf{3 9 , 5 1 5}$ \\
\hline
\end{tabular}

Similarly, the calculations under the model (2) were made for the lease payment schedule from the perspective of the lessor. The results of calculations are shown in Table 3.

Table 3. Results of calculations for model (2)

\begin{tabular}{ccccccc}
\hline Period (year), $i$ & $q_{i}$ & $r_{i}^{0}$ & $C_{i}$ & $H_{i}-z_{i}$ & $\Phi(r)$ & Discounted $\Phi(r)$ \\
\hline 1 & 108,8 & 9,79 & 2 & 9,792 & 7,79 & 6,776 \\
2 & 110 & 9,9 & 2 & 9,9 & 7,90 & 5,974 \\
3 & 110 & 9,9 & 4 & 9,9 & 5,90 & 3,879 \\
4 & 112 & 10,08 & 4,5 & 10,08 & 5,58 & 3,190 \\
5 & 120 & 0,33 & 5 & 10,8 & $-4,67$ & $-2,323$ \\
6 & 120 & 0 & 5,5 & 10,8 & $-5,50$ & $-2,378$ \\
7 & 120 & 0 & 5,5 & 10,8 & $-5,50$ & $-2,068$ \\
8 & 120 & 0 & 5,5 & 10,8 & $-5,50$ & $-1,798$ \\
9 & 120 & 0 & 5,5 & 10,8 & $-5,50$ & $-1,563$ \\
10 & 120 & 0 & 5,5 & 10,8 & $-5,50$ & $-1,360$ \\
Total & & $\mathbf{4 0}$ & & & $\mathbf{- 5 , 0 0}$ & $\mathbf{8 , 3 3 0}$ \\
\hline
\end{tabular}

A graphic illustration of the results obtained is presented in Figure 3.

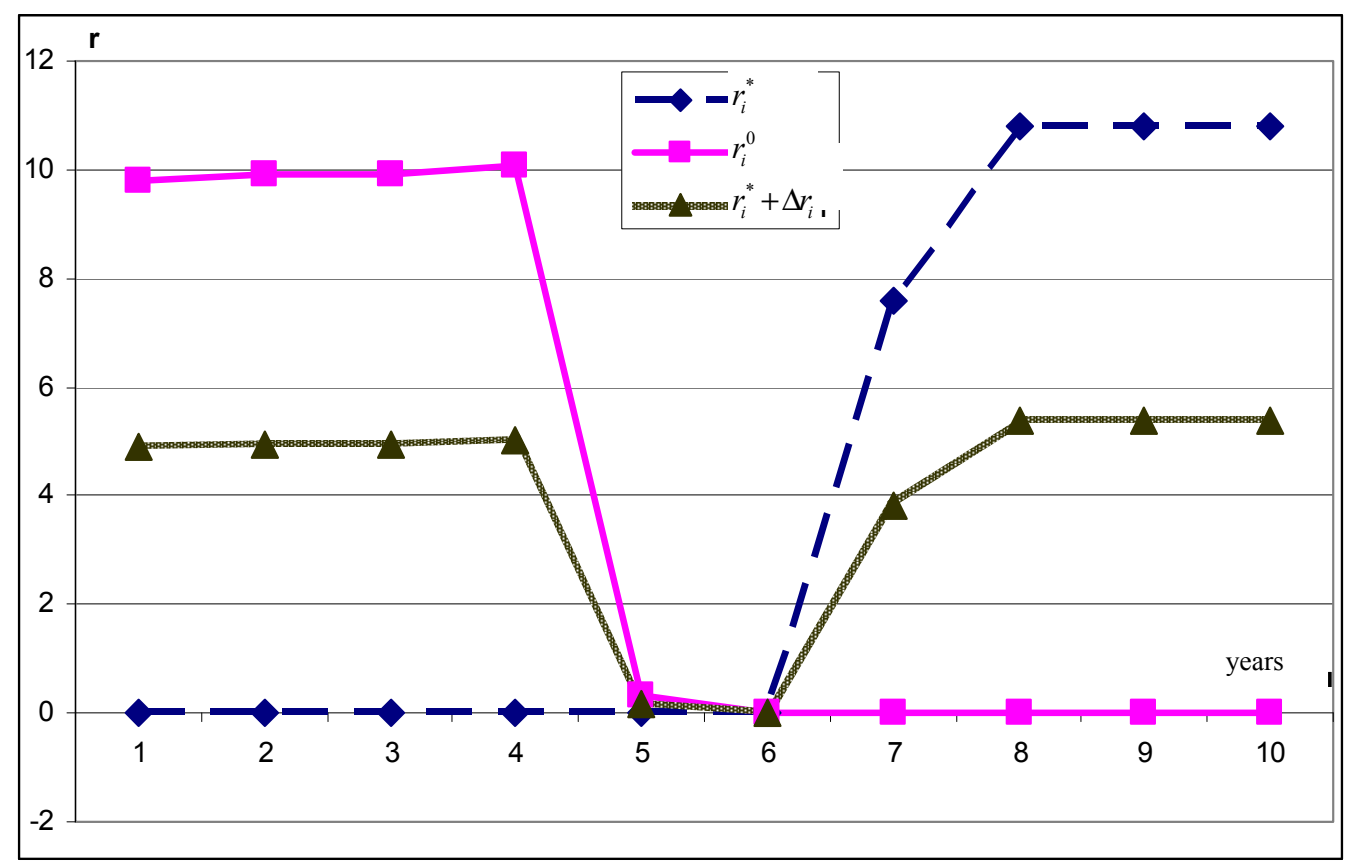

Figure 3. Illustration of the results 
The obtained results clearly illustrate the contradictions of the economic interests of the participants in leasing relations that have taken place. Using the model (3) there were calculated corrective actions $\Delta r_{i}$, which provide the coordination of the participants' interests and, at the same time, ensure fulfillment of the conditions of the lease agreement. The calculation results are also shown in Figure 3.

Thus, the developed complex mathematical models and approaches can solve the problem of coordination of economic interests of the lessor and the lessee in the scheduling of lease payments.

\section{Conclusions}

Summarizing the article we can pick out following research results:

- There is designed a model of payment flows that characterizes the interaction between the participants in the aviation leasing project;

- There is offered a mathematical model for choosing lessors lease payments schedule, taking into account its economic interests;

- There is formulated a mathematical model of decision making for lease payments, which reflects the economic interests and capabilities of the lessee;

- There is developed a model of the lease payments schedule forming for coordinating economic interests of participants interacting in the "lessor-lessee" system.

Received general theoretical and applied results allow us to extend them to a wide range of businesses using a leasing form for changing equipment. The developed models and methods of leasing relations can be used in the preparation and implementation of leasing contracts between leasing and aviation companies. The proposed models and methods can be recommended for use in other cooperating companies and organizations.

\section{References}

Bazargan, M., \& Hartman, J. (2012). Aircraft replacement strategy: Model and analysis. Journal of Air Transport Management, (25), 26-29. http://dx.doi.org/10.1016/j.jairtraman.2012.05.001

Chemmanur, T., Jiao, Y., \& Yan, A. (2010). A theory of contractual provisions in leasing. Journal of Financial Intermediation, (19), 116-142. http://dx.doi.org/10.1016/j.jfi.2007.09.002

Degl'Innocenti, M., Girardoneb, C., \& Torluccioc, G. (2014). Diversification, multimarket contacts and profits in the leasing industry. Journal of International Financial Markets, Institutions and Money, (31), 231-252. http://dx.doi.org/10.1016/j.intfin.2014.04.001

Edlin, R., Hall, P., Wallner, K., \& McCabe, C. (2014). Sharing Risk between Payer and Provider by Leasing Health Technologies: An Affordable and Effective Reimbursement Strategy for Innovative Technologies? Value in Health, (17), 438-444. http://dx.doi.org/10.1016/j.jval.2014.01.010

Ezzell, J. R., \& Vora, P. P. (2001). Leasing versus purchasing: Direct evidence on a corporation's motivations for leasing and consequences of leasing. The Quarterly Review of Economics and Finance, (41), 33-47. http://dx.doi.org/10.1016/S1062-9769(00)00060-0

Gavazza, A. (2010). Asset liquidity and financial contracts: Evidence from aircraft leases. Journal of Financial Economics, (95), 62-84. http://dx.doi.org/10.1016/j.jfineco.2009.01.004

Lin, J.-R., Wang, C.-J., Chou, D.-W., \& Chueh, F.-C. (2013). Financial constraint and the choice between leasing and debt. International Review of Economics \& Finance, (27), 171-182. http://dx.doi.org/10.1016/ j.iref.2012.09.012

Ouma, T. H., Zhangb, A., \& Zhangc, Y. (2000). Optimal demand for operating lease of aircraft. Transportation Research Part B: Methodological, (34), 17-29. http://dx.doi.org/10.1016/S0191-2615(99)00010-7

Rosskopf, M., Lehner, S., \& Gollnick, V. (2014). Economic-environmental trade-offs in long-term airline fleet planning. Journal of Air Transport Management, (34), 109-115. http://dx.doi.org/10.1016/j.jairtraman. 2013.08.004

\section{Copyrights}

Copyright for this article is retained by the author(s), with first publication rights granted to the journal.

This is an open-access article distributed under the terms and conditions of the Creative Commons Attribution license (http://creativecommons.org/licenses/by/3.0/). 